\title{
More Useful Londons: The Comparative Development of Alternative Concepts of London
}

\section{Paul C. Cheshire, Galina Gornostaeva, London}

\section{Introduction - alternative definitions - a brief overview}

In this paper we want to analyse the development of London in the context of the development patterns of the other large European cities most closely comparable with London. Such an analysis has to be predicated on a precise definition of what London is and, of course, on similar definitions of the other cities with which London is being compared.

One of the peculiarities of Europe is that each country has its own idea of what a "city» is, and it is often quite difficult for even students of urban development to grasp that the definition they have grown used to in their lives and work is not that used in other countries. There is even less recognition of how vital a common definition is if valid comparisons of demographic, economic and social development patterns are to be made. At the risk of causing offence and certainly at the risk of over-simplification, let us try to characterise national positions.

Most Belgians have great difficulty with the idea that Brussels extends beyond the confines of its regional administrative boundaries which define the limits of the national bi-lingual zone and contain less than one million inhabitants. If one examines the metropolitan region of Brussels, however, defined as the sphere of economic influence of the Brussels employment concentration, it covers nearly four million inhabitants and extends over a third of Belgium. The French have various administrative definitions of cities, with some extra ones available for Paris. In normal cases they identify cities in terms of their central commune. However, a handful of large cities have a Communité Urbaine - a federation of Communes relating to the city. For comparative purposes, the French typically rely on the concept of the agglomération - a morphological definition based primarily on the density of buildings. Such a definition applied in France produces broadly comparable definitions since it embraces whole cities. Problematic are the more densely urbanised regions of northern and eastern France which require additional criteria. The term has the additional advantage that it can be quantified using remote sensing techniques. If it is applied to Belgium, however, the whole country from Antwerp to Liège turns out to be one city: a result with which neither Belgians nor students of urban development should be satisfied. Equally, the agglomération definition does not produce comparably complete definitions of cities when applied to Britain or to the Netherlands. There, land use planning policies have deliberately prevented contiguous urbanisation. The Germans use a legal definition of cities - the Kreisfreie Stadte - with which they are generally content, especially if they are politicians or students of political science. Other unofficial definitions exist but are not widely used.

The British seem to be prepared simply to accept current political/administrative definitions, although these have been quite remarkably unstable in the past 30 years and especially so in the case of London. Scholars do produce definitions of British cities based on functional criteria (of which those originating from the Centre for Urban and Regional Development Studies at the University of Newcastle are probably the best known). The Census of Population produces data for «built-up areas» (equivalent to the French agglomeration), but neither of these terms are in wide use, even by specialists.

Accepting administrative definitions of cities in Britain requires an extraordinary, some might say, excessive degree of flexibility. They have changed frequently over the past 30 years or so, and their changes have been mainly driven by short term political considerations. In 1963 London was defined as the County of London. This corresponded with what is now known by those interested in the more arcane reaches of urban statistics as Inner London. When the Greater London Council (GLC) was brought into existence it became the administrative area of London and took over the popular concept of what London was. Already, of course, the functional reality of London was a good deal bigger. Even Heathrow is only partly within the boundary of the GLC and now both the other major London airports are entirely outwith those boundaries. In the mid-1980s the GLC was abolished leaving only a ghostly concept of London behind. Even Londoners could not reconcile themselves to what was now the only political unit called London - the medieval City. Although in 1971 this area offered 230000 jobs, it had less than 6000 residents. Most recently, in 2000 , the Greater London Authority (GLA) was recreated using - for political reasons - the old boundaries of the 1964 GLC. The GLA - even with its short existence - seems already to have become the familiar idea of London. 
Thus Europe suffers from a plethora of national definitions of «cities», and even within single countries definitions can vary widely between cities. From across the Atlantic, or if one is a student of European comparative urban development, this looks silly. In the US two parallel definitions of «cities» are widely accepted and co-exist in harmony. There are the administrative/ political units known as central cities and then, for statistical purposes, there is an official set of functionally defined metropolitan or urban regions. The latter, first defined for the 1940 census of population, have been variously called (Standard) Metropolitan Statistical Areas. They relate to areas defined primarily by the structure of employment and density of population, as well as areas linked by commuting flows. Their advantages for comparative and analytical purposes are obvious: they are defined according to consistent criteria, and they capture the whole of each individual economic and social system that constitutes a «city». This is not to claim that they are perfect, nor are we interested here in the details of their definition. Whatever their shortcomings or inconsistencies, the data sets based on them are orders of magnitude more useful than anything available for European cities.

The problems associated even with such a simple variable as urban size are obvious. To get valid values it is essential to measure population over areas that bear a consistent relation to the actual urbanised area. Comparisons based on, for example, the size of administrative units, such as «central cities», will be influenced as much by the accident of boundaries as by the actual size of urban areas. A US city, such as St. Louis, where there has been considerable decentralisation but no consolidation of suburbs with the central city for a century will have a small apparent population; in a European context the extreme example is provided by London, where the City of London had a population of only 4,500 residents in 1991.

If population or employment decline is to be separated from decentralisation, it is essential to include areas receiving decentralisation within the definition of metropolitan areas. If comparisons are being made for indicators of prosperity or social conditions - such as unemployment or deprivation - it is again critical that inclusive and consistent definitions of cities are used. If they are not, then systematic patterns of residential segregation (whether as in Paris or Glasgow, where the more poor and deprived tend to live in peripheral social housing or, as in most US cities, where they are concentrated in central areas) will distort measures. If the definition of «city» varies in such exercises, then the apparent incidence of, say, unemployment will depend as much on whether the specific areas where the unemployed are concentrated were included for particular cities, as it will on the actual nature of local economic conditions. It is even more important to have comparable and inclusive definitions of cities if the comparison is international since patterns of residential segregation vary more systematically between countries than within them.

Perhaps most crucially of all, it is essential to have inclusive and comparable definitions of cities if several variables are being related to each other. This happens, for example, in the calculation of Gross Domestic Product per head or unemployment rates. GDP per capita is one of the most widely used indicators of prosperity and is used by the European Commission as the prime indicator for regions which are poor rela-

\begin{tabular}{|l|r|r|r|r|}
\hline & $\mathbf{1 9 9 8}$ & $\mathbf{1 9 9 7}$ & $\mathbf{1 9 9 6}$ & $\mathbf{1 9 9 5}$ \\
\hline Greater London & 157.4 & 151.6 & 126.4 & 124.4 \\
\hline Inner London & 250.6 & 242.1 & 202.1 & 200.1 \\
\hline Inner London -West & 461.9 & 448.6 & 377.3 & 373.1 \\
\hline Inner London - East & 129.1 & 124.4 & 103.4 & 103.5 \\
\hline Outer London & 99.4 & 95.5 & 79.6 & 77.6 \\
\hline Outer London - East \& North East & 77.8 & 74.2 & 61.5 & 59.8 \\
\hline Outer London - South & 95.3 & 91.5 & 76.3 & 76.1 \\
\hline Outer London - West \& North West & 120.9 & 117.1 & 98 & 94.9 \\
\hline South East & 116 & 110 & 91.5 & 86.8 \\
\hline
\end{tabular}

Tab. 1: GDP per capita for different Londons 1995-98: relative to EU of 15

Le produit social brut par habitant, comparé à la moyenne européenne, selon des définitions variées des délimitations de Londres

Bruttosozialprodukt pro Kopf, im Vergleich zum europäischen Durchschnitt, für unterschiedlich definierte Abgrenzungen Londons

Source: REGIO 
tive to the EU as a whole and so are thought to be deserving of assistance. Yet since GDP or output is calculated at workplaces and population is counted at place of residence, if there is net inward or outward commuting into the area used to delimit a city, then the measure of GDP per capita will not give a valid indication of the living standards in that area. Table 1 shows this dramatically for London.

The South East is the encompassing NUTS (Nomenclature des Unités Territoriales Statistiques) Level 1 region with a population of about $17.5 \mathrm{~m}$, compared to about 7 million in Greater London. Greater London is the main concentration of employment in the South East and has substantial net in-commuting. Thus, a significant part of the apparent superior prosperity of Greater London compared to the South East is the result of the fact of net in-commuting. Within London, employment is concentrated in Inner London - in the City, Docklands and the West End. Into these areas there is an even greater proportionate inflow of commuters relative to employ- ment. The result is that prosperity is systematically even more overstated as the focus narrows onto those areas with successively greater concentrations of jobs relative to residents. This peaks in Inner London - West which is consequently recorded as the «richest» region in the EU. But that, of course, is nonsense. It does, however, have the probably not accidental effect of relegating Outer London - East \& North to the category of a deprived region and so qualifying it for assistance from the EU structural funds.

The first essential of useful comparative analysis both of a city's own pattern of development and of its development relative to other cities - is thus to have a comparable definition of «city» which is appropriate for the purpose in hand. In the case of the most of this paper, comparisons are on the basis of functionally defined urban areas (Functional Urban Regions or FURs). These are defined on the basis of concentrations of employment and then spheres of economic influence defined by commuting patterns. In

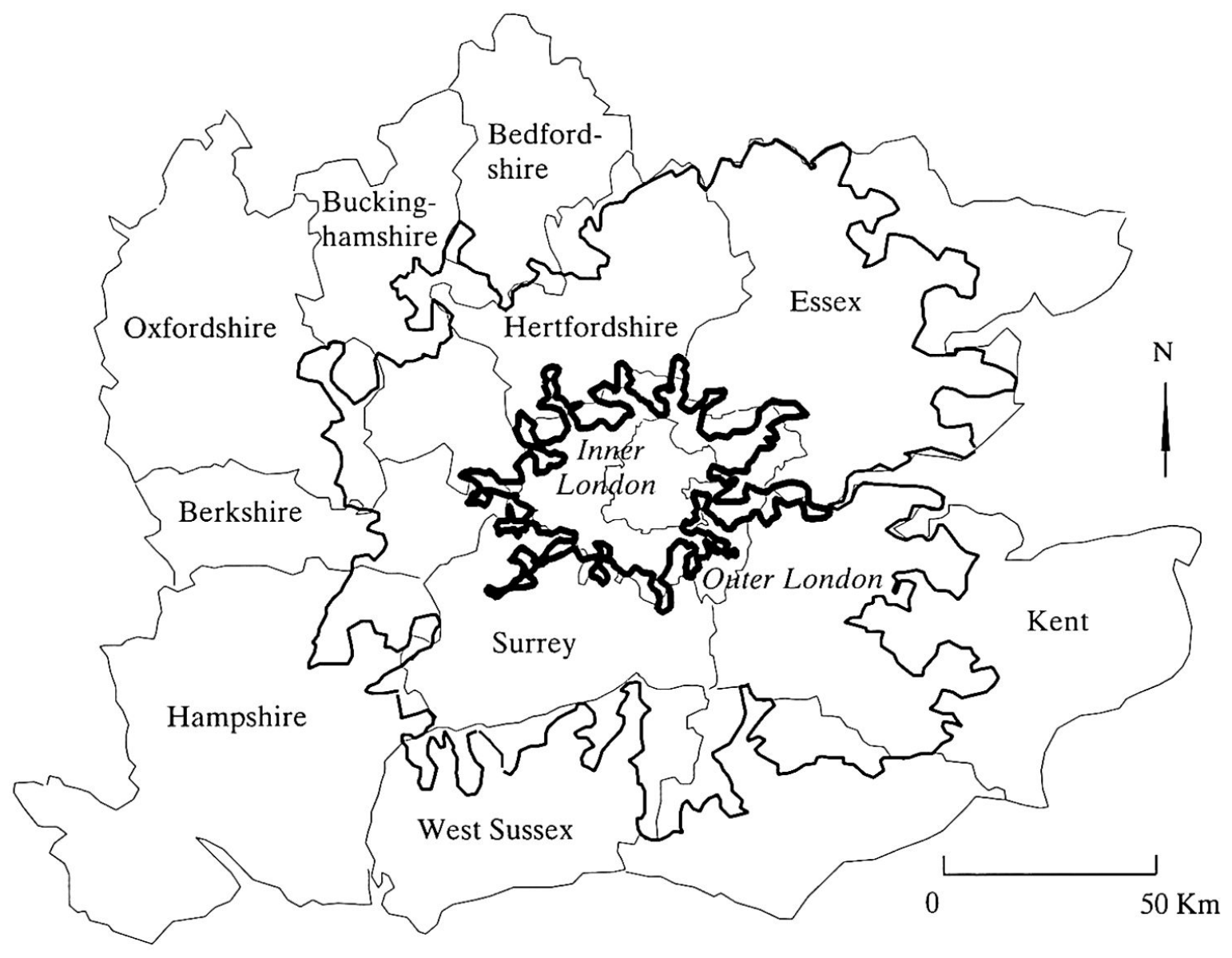

Map 1:The Greater London Area according to statistical regions set by the European Union (South-East-NUTS 1 and counties-NUTS 3), as well as by functional definition (London-FUR91)

Le Grand Londres selon les régions statistiques de l'Union européenne (NUTS1 et NUTS3) et des structures fonctionnelles (FUR91).

Der Grossraum London nach statistischen Regionen der Europäischen Union (NUTS1 und NUTS3) und funktionalen Gliederungen (FUR91)

Source: Commuting data from special workplace statistics (Census of PopUlation 1991) 


\begin{tabular}{|l|c|c|c|c|c|c|c|}
\hline \multicolumn{1}{|c|}{ Unit } & 1971 & 1981 & 1991 & 1996 & \multicolumn{2}{|c|}{$1996 \%$} & $\begin{array}{c}\% \\
\text { Change } \\
\text { 1981-96 } \\
\text { Inner London }\end{array}$ \\
& 2771 & 2550 & 2627 & 2708 & 13.7 & $\ldots$ & 6.2 \\
\hline Outer London & 4681 & 4255 & 4263 & 4367 & $\ldots$ & $\ldots$ & 2.6 \\
\hline Greater London & 7452 & 6805 & 6890 & 7075 & 15.3 & 24 & 4.0 \\
\hline South East & 17230 & 17011 & 17637 & $(16778)$ & $(17.0)$ & $(14)$ & $(6.5)$ \\
\hline
\end{tabular}

Tab. 2: London's population: administrative definitions 1961-96

La population de Londres selon des délimitations administratives variées (1961-1996)

Die Bevölkerung Londons nach unterschiedlichen administrativen Abgrenzungen 1961-1996

Source: Regional Trends

the case of London, the core of its Functional Urban Region (FUR) corresponds quite closely to the area of Greater London. These divisions into a core city and its hinterland can be used to analyse patterns of decentralisation or recentralisation.

Two separate London FURs are analysed here. FUR71 was defined - originally by HALL \& HAY (1980) on the spatial patterns of employment and commuting which existed in 1971; the FUR91 on those of 1991. The London FUR91 used slightly different commuting criteria for defining the hinterland boundaries and was defined for an INTERREG IIC project - GEMACA II - funded by the EU. It is, however, in concept broadly comparable to the FUR71. As can be seen in Map 1 - which shows the boundaries of London FUR91 together with the commonly used administrative definitions - this London extended over an area of $150 \mathrm{kms}$ from east to west. It had a population of 12.5 million.

A final introductory point relates to our aim of analysing London's comparative development trends: the issue is comparative to what? The most obviously comparable city in Europe is Paris. This is the only other city in Western Europe of similar size, and with many similar functions. Other comparator cities chosen were Amsterdam, Brussels, Dublin, Düsseldorf, Edinburgh and Frankfurt. These are much smaller but do share some similar functions in the European and world economies. Amsterdam is not only smaller, but it is part of a closely interacting set of four cities composing the Randstad. Between these cities there is strong functional specialisation, and their physical patterns of development have been significantly determined first by topography and more recently by a strong and determined effort of public policy: the Dutch land use planning system which has developed a «Green Heart Metropolis». We cannot use Berlin because its unification is too recent and data are far too poor. Zurich, although it has some functional parallels with London, lacks others (it is not a capital, for example, nor a port) and is outside the EU, so has so far felt the impact of European integration less. There are three other large cities in the EU - Athens, Barcelona and Madrid but these are all in economic and social contexts differing widely from those common to the large cities of Northern Europe.

\section{The development of administrative and functional Londons}

The population of what is now the administrative unit of Greater London started to fall from 1939. Comparing its migration balance with the rest of the UK shows that the maximum rate of loss from this source was in the early 1970s. It was high throughout the 1960 s but declined from about 1973, recovering for a few years in the early 1980s (Champion \& Congdon 1987). Since then, the migration balance with the rest of the UK has bumped along close to zero. The result of this and other changes discussed below is that in the first few years of the 1980s there was not just gain from migration but population gain overall for Greater London for the first time in 50 years. After falling back during the later 1980 s, this trend resumed in the 1990s. Because of data availability problems it is easiest to track the changes for administrative units. It can be seen from Table 2 that the population of Inner London grew by $6.2 \%$ between 1981 and 1996, with half of that gain occurring between 1991 and 1996. The population of the GLC area also grew between 1981 and 1996 but not as fast as that of Inner London. 


\begin{tabular}{|c|c|c|c|}
\hline Borough & $\%$ Change & Borough & $\%$ Change \\
\hline Tower Hamlets & $21.6(\mathrm{I})$ & Havering & $-4.7(\mathrm{O})$ \\
\hline Kensington \& Chelsea & $13.5(\mathrm{I})$ & Brent & $-2.6(\mathrm{O})$ \\
\hline Richmond-upon-Thames & $11.2(\mathrm{O})$ & Greenwich & $-1.6(\mathrm{O})$ \\
\hline Merton & $8.7(\mathrm{O})$ & Bromley & $-1.0(\mathrm{O})$ \\
\hline Westminster & $8.4(\mathrm{I})$ & Enfield & $0.6(\mathrm{O})$ \\
\hline Barnet & $8.2(\mathrm{O})$ & Redbridge & $0.6(\mathrm{O})$ \\
\hline
\end{tabular}

Tab. 3: Fastest and slowest growing London boroughs: 1981-96

$(\mathrm{I})=$ Inner London; $(\mathrm{O})=$ Outer London

Les portions urbaines dont la croissance est la plus rapide ou la plus lente (1981-1996)

Die am schnellsten und am langsamsten wachsenden Stadtteile: 1981-96

Source: Regional Trends, I/98

The growth of Inner London's population was helped by the redevelopment of London's docklands but that was far from the sole explanation. Table 3 shows the change in population for the six fastest and the six slowest growing London Boroughs. From this we can see that there was a general tendency for Inner London Boroughs to grow systematically faster than those in Outer London. Half the fastest growing Boroughs were in Inner London, but none of the slowest growing ones were. And only one of the fastest growing Boroughs - Tower Hamlets - benefited from dockland redevelopment. There is now little derelict industrial land or abandoned buildings left in Inner London. It is not just land in docklands that has been redeveloped. Land throughout Inner London has been redeveloped both piecemeal and in large chunks, mainly for housing. Old workshops in 19th and early 20th Century artisan areas and small scale industrial buildings (as in the former clock making district, Clerkenwell, which borders the City to the north) have been converted for the recently fashionable loft living.

However, such «gentrification» of Inner London is not the only, and perhaps not the most important, source of the change in the trajectory of London's population. Although the rapid loss of population through out-migration in Greater London of the 1960s and 1970s is now finished, the GLC area still tends to have a negative in-migration balance in most years. The major sources of population gain are international migration and natural increase. Between 1981 and 1996 about $35 \%$ of all international migrants coming to England came to Greater London. In 1996 some $24 \%$ of London's population was classified as members of an ethnic minority compared to $7 \%$ of that of England as a whole. This international migration, however, is not by any means only from the third world. In 1998 there were 200,000 US nationals registered as living in London and 60,000 French nationals.

London's cosmopolitan nature is central to its character. It was founded by the Romans, occupied by first Germans and then by Normans (themselves a mixture of Scandinavian and French). In more recent times its ethnic mix has been reinforced both by a relatively liberal attitude to immigration and religious minorities, as well as by London's role as the capital of a

\begin{tabular}{|c|c|c|c|c|}
\hline & 1981 & 1986 & 1991 & 1996 \\
\hline London gross inflow as \% of England & 35.5 & 35.0 & 33.9 & 37.4 \\
\hline London net balance ('000) & -6 & 27 & 7 & 37 \\
\hline
\end{tabular}

Tab. 4: International migration into GLC London

La migration internationale dans le Greater London Council (GLC)

Internationale Migration in den Greater London Council (GLC) London

Source: Regional Trends 


\begin{tabular}{|c|c|c|c|c|}
\hline & 1981 & 1991 & 1995 & 1997 \\
\hline Labour Force (1'000s) & 3445 & 3541 & 3476 & 3539 \\
\hline \% Employees in employment: & & & & \\
\hline Industry & 17 & 11 & $\ldots$ & 9 \\
\hline Construction & 5 & 4 & $\ldots$ & 3 \\
\hline Distribution, Hotels, Catering \& Repairs & 19 & 20 & $\ldots$ & 21 \\
\hline Transport \& Communications & 10 & 9 & $\ldots$ & 8 \\
\hline Banking, Finance \& Business Services & 16 & 23 & $\ldots$ & 31 \\
\hline Public Administration \& Defence & 5 & 8 & $\ldots$ & 7 \\
\hline Education, Health \& Other Services & 24 & 25 & $\ldots$ & 22 \\
\hline
\end{tabular}

Tab. 5: Employment and labour force: GLC area

Emplois et travailleurs dans le Greater London Council (GLC)

Beschäftigung und Arbeitskräfte im Gebiet des GLC (Greater London Council)

Source: Regional Trends and Census

world trading empire and its continuing importance in the English speaking (and therefore international business) world. London had significant Jewish areas in the Middle Ages; it was the destination of large scale Huguenot migration in the 16th and 17th Century and the destination of Jewish refugees, as well as of immigrants from all over continental Europe and the (ex)British Empire in the 19th and 20th Century. In the early 20th Century some of the largest foreign urban concentrations of Italians or Greeks were in districts of London. Now, whole neighbourhoods of London are Muslim, indeed, not just Muslim but Turkish Muslim or Bangladeshi Muslim. Other neighbourhoods are Punjabi, Caribbean or Chinese.

If the current trends in births, deaths and migration are maintained, the population of Greater London is expected to continue to grow by another 3 percent by the year 2006. In addition, current land use planning objectives seek to accommodate as much as possible of household growth on recycled land within the urban cores, in order to limit development of green field sites. This could add to population growth in Greater London.

As was argued in CHESHIRE (1995), however, the forces generating renewed population growth in major cities, and especially in London, are primarily economic and demographic. Falling household size coupled with increased female participation in the labour force increase the advantages of a location central to the labour market and reduce the relative attractions of garden space. In addition, changes in working practices in service industries and their growth to dominate urban employment have greatly increased the length of the working day. This is particularly true in London where its ability to compete as a global financial centre requires long working hours. Long working hours in turn generate a demand for local services such as restaurants and bars and a demand for living closer to the job to save travel-time to work. This particular motive may have been re-inforced in London because of the deterioration in public transport. With London transport and the commuter rail links performing as poorly as they have been since the 1980 s, the advantages of central living for those with jobs in Inner London has been further strengthened.

At the same time the population aged 65 and over has been falling steadily in Greater London - by a total of 11 percent since 1981 . By 1996 only about one person in eight in Greater London was aged 65 or over compared to one in six for the South East as a whole. This decline may in part reflect an adjustment to much higher housing costs within London than in other parts of (even southern) England. Housing costs in Inner London particularly make it a less attractive location for people not actually working there and seem to have led to a life cycle pattern in which owner occupied housing is viewed as a part of a portfolio of assets. A move to cheaper housing outside London at retirement thus becomes a part of peoples' financial planning for retirement.

Reflecting these trends, the number of households in Greater London has been rising steadily since 1981, to 3 million in 1996. Growth has been particularly strong in Inner London and, of course, has been faster than population growth, since the average number of people in each household has fallen steadily over 


\begin{tabular}{|ccc|}
\hline \multicolumn{1}{|c}{ Economic Sector } & \% by Sector & \% Change 1991-98 \\
\hline $11 \mathrm{~K}:$ Real estate, renting, business activities & 21,2 & 7,74 \\
$7 \mathrm{G}:$ Wholesale/retail trade; repair, etc & 17,6 & 4,60 \\
$4 \mathrm{D}:$ Manufacturing & 11,1 & 3,39 \\
$14 \mathrm{~N}:$ Health and social work & 8,4 & 2,66 \\
$9 \mathrm{I}:$ Transport, storage and communication & 7,2 & 2,19 \\
$13 \mathrm{M}:$ Education & 7,0 & 1,46 \\
$10 \mathrm{~J}:$ Financial intermediation & 6,4 & 0,26 \\
$8 \mathrm{H}:$ Hotels and restaurants & 5,9 & 0,01 \\
$15 \mathrm{O}:$ Other community, social/personal service & 5,4 & 0,00 \\
$12 \mathrm{~L}:$ Public administration/defence; social security & 5,2 & $-0,07$ \\
$6 \mathrm{~F}:$ Construction & 4,0 & $-0,83$ \\
5 E : Electricity, gas and water supply & 0,4 & $-2,11$ \\
$3 \mathrm{C}:$ Mining and quarrying & 0,1 & $-3,16$ \\
$1,2 \mathrm{~A}+\mathrm{B}:$ Agriculture, hunting and forestry, fishing & 0,0 & $-6,93$ \\
\hline
\end{tabular}

Tab. 6: Employment structure according to the functional urban region of London in 1991 (FUR91), 1991-98 (Note the figures for agriculture etc. relate to very small bases and are misleading for urban areas.)

La structure des emplois: Les régions urbaines fonctionnelles de Londres-FUR91 (1981-1998)

Beschäftigungsstruktur: London Functional Urban Regions-FUR91, 1991-98

Source: FUR database

the same period. The average number of people per household in Inner London is 2.2, less than the average in Outer London (2.4), which is close to the average for Great Britain.

Tables 5 and 6 show the structure of employment for the GLC area and the area of the London Functional Urban Region (FUR91) as defined on 1991 data. The longer time series available for the GLC area requires a more restricted set of economic sectors. The message is relatively clear, however. In the GLC area - which as can be seen from Map 1, approximately corresponds to the area of the economic core of the London FUR91industry has all but disappeared although it is more significant and was in proportionate terms growing in the FUR91 as a whole. In the GLC area high level services dominate with construction and transport accounting for only 11 percent of employment by 1997. The economy of the wider area of the London FUR91 is still specialised in business and financial services and health and education but to a significantly lesser extent. Such activities are concentrated in the more central area

The international character of London reflects its position as a global city and is reflected in its economic character. London's airports account for about $35 \%$ of all the passengers using the five major hub cities of Europe. Table 7 illustrates another aspect of this international economic function. London's economy is not just dominated by high level service functions, it is also a major centre for business decision making. It is the pre-eminent European location of the HQs of multinational firms. It is not just that London and Paris between them account for half the headquarters of Europe's top 300 companies and that almost a quarter more are located in London than Paris. London has a comparative specialisation in the very highest level business functions. While relatively more HQs are located in London, relatively fewer of the same companies' subsidiaries have their HQs in London as well.

\section{London compared to other European cities}

As was stated in the introduction, the most obvious European city with which to compare London is Paris. Table 8 shows the population development of these two cities from 1951-97 defined on constant 1971 boundaries. Using those boundaries defined on the basis of employment location and commuting patterns recorded in 1971 provides a longer time series. However, the contrast with the results for the 1991 bounda- 


\begin{tabular}{|c|c|c|}
\hline City & \% Headquarters & \% of Subsidiaries \\
\hline London & 28 & 5.0 \\
\hline Paris & 22 & 8.8 \\
\hline Brussels & 3 & 5.3 \\
\hline Frankfurt & 3 & NA \\
\hline Milan & 1 & 5.3 \\
\hline Barcelona & 0 & 5.2 \\
\hline
\end{tabular}

Tab. 7: Location of top 300 multinational companies (in \%)

Localisation des 300 firmes multinationales les plus importantes (en \%)

Standorte der 300 grössten multinationalen Unternehmen (in \%)

Source: adapted from Rozenblat \& Pumain 1993

ries and the built-up areas (agglomeration) is also of interest. These are shown in Table 9.

Data for 1997 are not available for the component core and hinterland of the FUR71 but the long term trend of population loss from the core of London's FUR is obvious. Hinterland growth was sufficient to offset core loss of population in London only until 1961. From then, within the constant boundaries reflecting commuting patterns of 1971, there was net loss of population until the late 1980s. The population loss of the 1980s, however, was almost exactly offset by the gain of the first half of the 1990s, with most of that gain being in the core - even the inner part of the core (Tables 2 and 3 ).
Over the whole period, the Paris FUR71 experienced population growth in all its components except for a slight loss from its core during the 1970s. Between 1951 and 1997, within the constant boundaries defined by the FUR71, Paris increased in size by some $60 \%$ while the London FUR71 lost about $8 \%$ of its population over the same period. Paris outstripped London as Western Europe's biggest city on this measure during the 1970s. Only during the 1990s has London's growth exceeded that of Paris.

Another feature of the difference between the two cities, however, is the size of their hinterlands relative to their cores. In London, about half the residents are

\begin{tabular}{|c|c|c|c|c|c|c|c|}
\hline \multirow{2}{*}{\multicolumn{2}{|c|}{ Functional Urban Region }} & \multicolumn{6}{|c|}{ Constant 1971 boundaries } \\
\hline & & $1951^{*}$ & $1961^{*}$ & $1971^{*}$ & $1981^{*}$ & $1991^{*}$ & $1997 *$ \\
\hline \multirow[t]{6}{*}{ London } & Core & 6417.0 & 6134.7 & 5593.9 & 4902.6 & 4639.2 & $\ldots$ \\
\hline & $\%$ growth & & -4.4 & -8.8 & -12.4 & -5.4 & \\
\hline & Hinterland & 3384.1 & 3840.1 & 4186.1 & 4146.9 & 4117.3 & $\ldots$ \\
\hline & $\%$ growth & & 13.5 & 9.0 & -0.9 & -0.7 & \\
\hline & FUR & 9801.1 & 9974.8 & 9780.0 & 9049.5 & 8756.5 & 9038.3 \\
\hline & $\%$ growth & & 1.8 & -2.0 & -7.5 & -3.2 & 3.2 \\
\hline \multirow[t]{6}{*}{ Paris } & Core & 6076.7 & 7358.2 & 8380.5 & 8332.3 & 8574.5 & .. \\
\hline & $\%$ growth & & 21.1 & 13.9 & -0.6 & 2.9 & \\
\hline & Hinterland & 728.7 & 843.8 & 1122.9 & 1740.7 & 2049.3 & $\ldots$ \\
\hline & $\%$ growth & & 15.8 & 33.1 & 55.0 & 17.7 & \\
\hline & FUR & 6805.5 & 8202.0 & 9503.3 & 10073.1 & 10623.8 & 10907.8 \\
\hline & $\%$ growth & & 20.5 & 15.9 & 6.0 & 5.5 & 2.7 \\
\hline
\end{tabular}

Tab. 8: London and Paris: Population 1951-97, within the Functional Urban Region defined in 1971 (FUR71) (1'000s) (*London and Paris adjusted to common dates)

La population de Londres et Paris (1951-1997), selon les régions urbaines fonctionnelles de Londres (FUR71)

Bevölkerung von London und Paris, 1951-97, nach Functional Urban Region (FUR71)

Source: FUR database 


\begin{tabular}{|c|c|c|l|}
\hline & \multicolumn{3}{|c|}{ Population in 1991 (1'000s) } \\
\hline & FUR71 & FUR91 & Built-up Area \\
\hline London & & & 7843.2 \\
\hline Core & 4639.2 & 6125.5 & \\
\hline Hinterland & 4117.3 & 6393.8 & \\
\hline FUR & 8756.5 & 12519.3 & \\
FUR growth 1981-91\% & -3.2 & 1.9 & \\
\hline & & & \\
\hline Paris & & & 9516.3 \\
\hline & & 7898.0 & \\
\hline Core & 8574.5 & 3520.0 & \\
\hline Hinterland & 2049.3 & 11418.0 & \\
FUR growth 1982-90\% & 10623.8 & 6.3 & \\
\hline
\end{tabular}

Tab. 9: London and Paris: Population according to different boundary definitions - FUR71, FUR91 and built-up areas Population et occupation du sol de Londres et de Paris, selon FUR71 et FUR91 Bevölkerung und besiedelte Fläche von London und Paris, nach FUR71 und FUR91 Source: FUR database and GEMACA database

in the hinterland defined by commuting flows: in Paris it is between 10 and $20 \%$. This feature of the two cities is reflected in the results shown in Table 9. First, the «size» of London is extremely sensitive to the definition taken whereas that of Paris is not. The FUR91 of London is $56.6 \%$ larger than its built-up area and $43.0 \%$ larger than it is when defined on constant 1971 commuting boundaries. Paris FUR91 is only $20 \%$ larger than its built-up area at the same date and only $7.5 \%$ larger than its FUR71. Second, if we look at the revised boundaries of the two FURs defined on a common basis but applying commuting patterns of 1991, we find that not only has London grown substantially since the definition of its 1971 boundaries but it is apparently larger than Paris: $9.6 \%$ larger rather than $21.3 \%$ smaller.

This is perhaps only a confirmation of the common view that London is particularly subject to long distance commuting. This is a long term historical difference between the two cities commonly believed to reflect the historic retention of city walls in Paris and the associated growth and retention of a concentration of upper socio-economic groups within the centre compared to the suburbanisation and subsequent exurbanisation of such groups from London (CHESHIRE \& Mills 1999). This historic difference has almost certainly been re-inforced by the very different policies of land use planning followed in Britain compared to France. In France, urban growth is in general allowed to take place by continuous additions to the existing urban boundary. In Britain, the land use planning system in place since 1947 requires the mainte- nance of constant urban boundaries and the protection of unbuilt land or «Green Belts» around urban areas. Growth of London has thus been significantly forced to leapfrog across green space to satellite communities. The result is more and longer distance commuting and quite possibly greater total energy consumption. These differences in land use planning policies themselves are likely to reflect the historic differences in the spatial distribution of upper, and politically more influential, social groups in the two countries. The British NIMBY lobby is typically an alliance of middle class left greens and right wing conservative ex-urbanites concentrated in the «Home Counties»-effectively the hinterland of London FUR91.

Tables 10 and 11 show the development of two key variables for the FUR71 of London and selected comparator European FURs. In each case the longest run of data available is shown. The GDP figures are estimated from Eurostat's REGIO database for the area of the FURs and, in addition, the data from 1995 onwards are re-estimated according to the same basis as the data for the period from 1977 to 1994. This is necessary because Eurostat introduced a new basis for estimating regional GDP figures in 1995, meaning that values from 1995 are not, in principle, comparable to those for the period 1977-94. Inevitably there is imprecision, therefore, in the data over and above those normally found in regional GDP estimates. Nevertheless, for reasons set out in the introduction, we are confident that estimating in this way to approximate values for functionally defined cities provides a much more secure foundation for comparisons across cities and 


\begin{tabular}{|l|r|r|r|r|r|r|r|}
\hline & \multicolumn{1}{|c|}{ Total } & \multicolumn{1}{|c|}{ London $=100$} \\
\hline & $\mathbf{1 9 5 1}$ & $\mathbf{1 9 5 1}$ & \multicolumn{1}{|c|}{$\mathbf{1 9 6 1}$} & \multicolumn{1}{c|}{$\mathbf{1 9 7 1}$} & \multicolumn{1}{c|}{$\mathbf{1 9 8 1}$} & \multicolumn{1}{c|}{$\mathbf{1 9 9 0}$} & \multicolumn{1}{c|}{$\mathbf{9 9 1}$} \\
\hline Amsterdam & 1912718 & 19.51 & 21.51 & 24.00 & 26.92 & 28.84 & 28.86 \\
\hline $\begin{array}{l}\text { Bruxelles- } \\
\text { Brussel }\end{array}$ & 2942867 & 30.03 & 31.37 & 33.69 & 37.33 & $\mathbf{3 9 . 0 4}$ & 38.82 \\
\hline Dublin & 957157 & 9.77 & 9.76 & 11.63 & 15.24 & 16.43 & 16.46 \\
\hline Düsseldorf & 1328910 & 13.56 & 17.13 & 19.92 & 20.01 & 20.93 & 20.91 \\
\hline Edinburgh & 707919 & 7.22 & 7.27 & 7.76 & 8.32 & $\mathbf{8 . 5 1}$ & 8.43 \\
\hline Frankfurt & 1591581 & 16.24 & 19.23 & 23.01 & 25.22 & 27.31 & 27.48 \\
\hline London & 9801133 & 100.00 & 100.00 & 100.00 & 100.00 & 100.00 & 100.00 \\
\hline Paris & 6805467 & 69.44 & 82.23 & 97.17 & 111.31 & 121.50 & 121.32 \\
\hline
\end{tabular}

\begin{tabular}{|l|r|r|r|r|r|r|r|}
\hline & \multicolumn{7}{|c|}{ London $=100$} \\
\hline & & $\mathbf{1 9 9 2}$ & \multicolumn{1}{c|}{$\mathbf{1 9 9 3}$} & \multicolumn{1}{c|}{$\mathbf{1 9 9 4}$} & \multicolumn{1}{c|}{$\mathbf{1 9 9 5}$} & \multicolumn{1}{c|}{$\mathbf{1 9 9 6}$} & \multicolumn{1}{c|}{$\mathbf{1 9 9 7}$} \\
\hline Amsterdam & & 29.05 & 29.15 & $\mathbf{2 9 . 1 5}$ & 29.06 & 28.93 & 28.81 \\
\hline $\begin{array}{l}\text { Bruxelles- } \\
\text { Brussel }\end{array}$ & 38.81 & 38.77 & 38.71 & 38.58 & 38.38 & 38.19 \\
\hline Dublin & & & & & & & \\
\hline Düsseldorf & & 16.61 & 16.64 & 16.61 & 16.63 & 16.70 & $\mathbf{1 6 . 8 8}$ \\
\hline Edinburgh & & $\mathbf{2 0 . 9 9}$ & 20.95 & 20.82 & 20.70 & 20.59 & 20.44 \\
\hline Frankfurt & & 8.41 & 8.42 & 8.44 & 8.46 & 8.43 & 8.41 \\
\hline London & & 27.81 & $\mathbf{2 7 . 9 7}$ & 27.89 & 27.77 & 27.67 & 27.55 \\
\hline Paris & & 100.00 & 100.00 & 100.00 & 100.00 & 100.00 & 100.00 \\
\hline
\end{tabular}

Tab. 10: Populations of selected functional urban regions defined on 1971 commuting patterns: 1951-97 (Figures in bold represent the high point relative to London.)

La population selon des FURs 1971 typiques, dans les secteurs de flux migratoires exogènes (1951-1997)

Die Bevölkerung ausgewählter FURs 1971, nach Pendlereinzugsbereichen 1951-97

Source: FUR database

regions than is possible using the data for the official NUTS regions or administratively defined cities. All data are shown relative to the values for London, except for the 1951 population which is also shown in absolute values.

Both series tell a consistent story. In terms of its population, London, defined as FUR71, was falling in size relative to other major European cities quite rapidly from 1951 to about 1990. In interpreting this statement it must be borne in mind, however, that part of this fall - perhaps a large part - was the result of the fact that London was decentralising more rapidly and leapfrogging out to new satellite centres to a far greater extent than other major European cities. We should bear in mind the extent to which revising the functional boundaries to reflect commuting patterns observed in 1991 increases the size of London compared to Paris. The relative reduction in London's size slowed or ceased in about 1990. In that year both
Brussel/Bruxelles and Edinburgh peaked relative to London FUR71 and by 1997 only Dublin was still growing relative to London. Again, these results are consistent with the re-centralisation process evident in London from the mid 1980s and noted above. A part of the change in trend may have been the product of the use of constant boundaries. Re-centralisation in London meant that within its old 1971 boundaries some of the re-centralisation appeared as growth.

The relative trends in GDP per capita figures suggest, however, that part of London's recovery in population reflected a relative improvement in the prosperity of its citizens. During the 1980s Paris did extraordinarily well in economic terms. Living standards in Paris improved relative to those elsewhere in France, whereas in most EU countries during the 1980s there was a fall in the living standards in the largest cities relative to the smaller cities and rural areas (CHESHIRE \& Carbonaro 1996). The major German cities improved 


\begin{tabular}{|l|r|r|r|r|r|r|r|r|}
\hline & \multicolumn{9}{|c|}{ London=100 } & \multicolumn{1}{|c|}{} \\
\hline & $\mathbf{1 9 7 7}$ & $\mathbf{1 9 7 8}$ & $\mathbf{1 9 7 9}$ & \multicolumn{1}{c|}{$\mathbf{1 9 8 0}$} & $\mathbf{1 9 8 1}$ & $\mathbf{1 9 8 2}$ & \multicolumn{1}{c|}{$\mathbf{1 9 8 8}$} & \multicolumn{1}{c|}{$\mathbf{1 9 8 9}$} \\
\hline Amsterdam & $\mathbf{9 6 . 5 9}$ & 92.45 & 91.50 & 93.15 & 91.63 & 90.54 & 79.91 & 81.67 \\
\hline $\begin{array}{l}\text { Bruxelles- } \\
\text { Brussel }\end{array}$ & 84.37 & 81.35 & 79.81 & 85.75 & 85.34 & 86.21 & 74.54 & 74.24 \\
\hline Dublin & 48.47 & 48.36 & 47.90 & 49.82 & 50.89 & 51.59 & 53.79 & 56.12 \\
\hline Düsseldorf & 116.35 & 111.88 & 113.36 & 116.13 & 115.62 & 113.82 & 105.70 & 106.73 \\
\hline Edinburgh & 72.19 & 71.66 & 72.62 & 73.53 & 75.49 & 75.06 & 79.46 & 80.35 \\
\hline Frankfurt & 111.26 & 109.15 & 112.52 & 121.11 & 119.23 & 119.46 & 125.48 & 128.99 \\
\hline London & 100.00 & 100.00 & 100.00 & 100.00 & 100.00 & 100.00 & 100.00 & 100.00 \\
\hline Paris & 127.49 & 123.08 & 124.02 & 126.07 & 126.30 & 131.85 & 119.85 & 120.61 \\
\hline
\end{tabular}

\begin{tabular}{|l|c|c|c|c|c|c|c|}
\hline & \multicolumn{7}{|c|}{ London=100 } \\
\hline & $\mathbf{1 9 9 1}$ & $\mathbf{1 9 9 2}$ & $\mathbf{1 9 9 3}$ & $\mathbf{1 9 9 4}$ & $\mathbf{1 9 9 5}$ & $\mathbf{1 9 9 6}$ & $\mathbf{1 9 9 7}$ \\
\hline Amsterdam & 89.38 & 88.23 & 88.32 & 89.35 & $\mathbf{9 5 . 1 4}$ & 91.24 & 93.88 \\
\hline $\begin{array}{l}\text { Bruxelles- } \\
\text { Brussel }\end{array}$ & 84.46 & 85.44 & 86.21 & 86.93 & $\mathbf{8 9 . 1 7}$ & 85.29 & 83.30 \\
\hline Dublin & 70.95 & 70.68 & 73.36 & 79.18 & 88.89 & 85.66 & $\mathbf{9 5 . 0 1}$ \\
\hline Düsseldorf & 122.24 & 120.88 & 115.99 & 118.37 & $\mathbf{1 2 2 . 6 3}$ & 113.51 & 112.39 \\
\hline Edinburgh & 84.72 & 89.13 & 91.38 & 92.75 & $\mathbf{9 4 . 4 2}$ & 93.16 & 92.31 \\
\hline Frankfurt & 152.36 & 150.61 & 146.65 & 148.95 & $\mathbf{1 5 4 . 2 8}$ & 144.77 & 143.77 \\
\hline London & 100.00 & 100.00 & 100.00 & 100.00 & 100.00 & 100.00 & 100.00 \\
\hline Paris & $\mathbf{1 3 5 . 6 8}$ & 132.11 & 129.10 & 129.11 & 131.02 & 122.04 & 118.44 \\
\hline
\end{tabular}

Tab. 11: Gross domestic product per capita purchasing power parity of selected functional urban regions defined on 1971 commuting patterns: 1951-97

(Figures in bold represent the high point relative to London.)

Le produit social brut par habitant selon les parités du pouvoir d'achat de FURs typiques dans les secteurs de flux migratoires exogènes (1951-1997)

Bruttosozialprodukt pro Kopf nach Kaufkraftparitäten ausgewählter, nach Pendlereinzugsbereich definierten FURs 1951-97

Source: FUR database

their living standards relative to both London and Paris continuously from 1977 through to the mid 1990s. Living standards in Amsterdam and Brussel/Bruxelles did not change greatly relative to those in London over the whole period although the different incidence of the economic cycle is evident as is the probable overstatement of London's boom of the late 1980s. Compared to all cities except Dublin, however, there does seem to have been a genuine change in trend from the early to mid-1990s with London becoming relatively more prosperous.

\section{Conclusions}

London's development pattern graphically illustrates the importance and problems of urban definition. The pattern we appear to observe from the data is radically different depending on whether one examines that data for administrative definitions of London or London defined on functional boundaries. Even the answer to such an apparently simple question as to whether London was growing or declining in population terms varies according to the definition of London taken; the ambiguity as to whether London was decentralising, re-centralising or declining is equally striking. Similarly, even different functional definitions can produce different pictures of the relative patterns of development of EU cities depending on whether those functional boundaries are fixed to reflect spatial patterns of employment and commuting at a given date or are updated to current spatial patterns of employment and commuting. 
This last conclusion reflects discussions in the US literature on the supposed phenomenon of counterurbanisation or disurbanisation and the revival of rural America that took place during the 1970s and 1980s (see, for example, Beale 1975, Berry 1976 or Frey 1993). This debate showed that apart from a very short period in the late 1960s and early 1970s, the rural revival was really the result of decentralisation and the urbanisation of previously rural counties contiguous to urban areas, and that a significant part of the urban revival of the 1980s was sensitive to whether constant boundaries of cities were used or whether they were extended to account for annexation. In the context of Europe we find that updating the functional boundaries of London makes much more difference to its measured size than is the case for Paris.

A pessimistic interpretation of this might be that no reliable measures of urban development at all are possible. This is, however, far too negative. It is clear that defining cities on the basis of functional boundaries makes better sense and provides more robust and sensible measures of development patterns than is the case if they are defined on administrative boundaries. It is almost equally as clear that if we want to have reliable comparative measures of city size or prosperity, then it is necessary to update those boundaries as actual spatial patterns of activity and economic interaction change. This may be particularly necessary in a European context because of the very substantial difference in institutional arrangements found in different countries. Not only are London and Londoners historically adapted to long distance commuting and strongly contrasting patterns of residential segregation compared to many continental European cities (and especially Paris), but these historic difference are re-inforced in land use planning policies which generate a strong force for London's growth to leapfrog across the South East of England spawning satellite centres as it goes. These satellite centres may take the form of essentially prosperous middle class dormitory exurbs, such as the Surrey villages or Henley, or they may take the form of significant satellite employment centres with their own commuting hinterlands but embedded in the penumbra of London: places like Guildford or Slough.

This pattern of London's decentralisation and relative economic and population decline appears to have changed in important ways since the mid 1970s. Perhaps the first indication of this change was in the trend of outmigration from the administrative unit of Greater London (roughly corresponding with the core of the London FUR) observed in around 1973 (and observed in other large northern European cities, such as Copenhagen at about the same time - MATTHIESSEN 1983). From then on, the population of London's core tended to stabilise; from the late 1980s it has grown for the first time in two generations. Over the whole period, the population of London's metropolitan region according to the FUR91 boundaries, tended to grow continuously, but at the same time until about 1990 to decentralise so extensively that its growth was invisible in official statistics. From about 1990 onwards, however, there has been absolute re-centralisation, absolute population growth and both absolute economic growth and growth relative to other large EU cities, except Dublin.

There are various drivers of this change although no definitive explanations. Some observers point to the growth of international migration. This, however, does not convince us as a complete explanation since had the trends of the 1960s and 1970s continued, London would have experienced continued loss and decentralisation despite the increase in international migration. In addition, the improvement in London's relative economic performance is not really consistent with this interpretation. Increases in international migration may be significant but they are not enough to explain what we observe. There appears to be powerful economic and demographic forces at work which have increased the advantages for central living and allowed London's economy to overcome the effects of the loss of most of its manufacturing sector during the 1960s and 1970s. Long hours, a strong demand for graduate workers and smaller households coupled with delayed marriage and age of starting a family all give rise to a demand for more central urban living. This, in turn, retains proportionately more of the income earned in London within London's economy, improving urban services and recreational facilities. But these forces are part also of the reasons underlying the serious increase in the inequality of household incomes and an intensification of polarisation in patterns of residential segregation.

\section{Acknowledgements}

We would like to acknowledge the help of our colleagues in the INTERRREG IIC funded project GEMACA II which allowed us to collect data on functionally defined cities of North West Europe using 1991 spatial patterns of economic activity and interaction. We would also like to acknowledge the contribution and criticism of our colleague Ian Gordon. The authors take responsibility for all errors.

\section{References}

Beale, C. L. (1975): The Revival of Population Growth in Non-Metropolitan America. - Washington D.C.: US Department of Agriculture, ERS 605.

BERRY, B.J. L. (1976): Urbanization and Counterurbanization. - Beverly Hills: Sage. 
Champion, A.G. \& P. Congdon (1987): An Analysis of the Recovery of London's Population Change Rate. In: Built Environment 13, 4: 193-211.

Cheshire, P.C. (1995): A New Phase of Urban Development in Western Europe? The evidence for the 1980s. - In: Urban Studies 32: 1045-63.

Cheshire, P.C. \& G. Carbonaro (1996): Urban Economic Growth in Europe: testing theory and policy prescriptions. - In: Urban Studies 33: 1111-28.

CheshiRe, P.C. \& E.S. Mills (1999): Introduction: Applied Urban Economics. - In: Cheshire, P.C. \& E.S. Mills (eds) (1999): Applied Urban Economics. Amsterdam (u.a.): North Holland: 1325-35.

FreY, W.H. (1993): The New Urban Revival in the United States. - In: Urban Studies 30: 741-77.

GEMACA (Group for European Metropolitan Areas Comparative Analysis) (1996): North West European Metropolitan Regions: Geographical Boundaries and Economic Structures. - Paris: IAURIF (Institut d'aménagement et d'urbanisme de la région d'Ile-de-France). HaLl, P. \& D.G. HaY (1980): Growth Centres in the European Urban System. - London: Heinemann Educational.

Matthiessen, C.W. (1983): Settlement change in Denmark. - In: MatThiessen, C.W. (ed.): Urban Policy and Urban Development in the 80s, Danish Experience in a European Context. - University of Copenhagen. Rozenblat, C. \& D. Pumain (1993): The location of multinational firms in the European urban system. In: Urban Studies 30: 1691-1709.

\section{Summary: More Useful Londons: The Comparative Development of Alternative Concepts of London}

London's development pattern graphically illustrates the importance and problems of urban definition. The pattern we observe is radically different depending on whether one examines the data for administrative definitions of London or London defined on functional boundaries. Even the answer to such an apparently simple question as to whether London was growing or declining varies according to the definition of London taken; the ambiguity as to whether London was decentralising, re-centralising or declining is equally striking. Even functional definitions of London and EU cities produce different pictures of the relative patterns of development, depending on whether those functional boundaries are fixed to reflect spatial patterns of employment and commuting at a given date or are updated to current patterns. For reasons we can identify, this makes much more difference to results in some cities than it does in others. Updating the functional boundaries of London, for example, makes much more difference to its measured size than is the case with Paris. London and Londoners are historically adapted to long distance commuting and strongly contrasting patterns of residential segregation compared to continental European cities (especially Paris). These have been re-inforced by land use planning which generates a strong force for London's growth to leapfrog across the South East of England spawning satellite centres as it goes. Despite these measurement problems, however, the evidence allows one to conclude that there has been a sharp change in trends in London both absolutely and relative to other major EU cities. Recently population has been growing and recentralising and London's economic performance improving.

\section{Zusammenfassung: Nützliche Stadtdefinitionen zu London: Die vergleichende Entwicklung von alter- nativen Konzepten Londons}

Das Entwicklungsmuster Londons illustriert die Bedeutung und die Probleme der städtischen Definition. Das Muster, das wir beobachten, unterscheidet sich grundlegend, je nachdem, ob man die Daten administrativer Definitionen Londons untersucht oder London durch funktionale Grenzen definiert. Selbst die Antwort auf die scheinbar einfache Frage, ob London wächst oder kleiner wird, hängt von der Definition Londons ab: die Mehrdeutigkeit, ob London sich dezentralisiert, sich wieder zentralisiert oder kleiner wird, ist ebenso treffend: Selbst funktionale Definitionen von London und von Städten der EU spiegeln unterschiedliche Bilder der relativen Entwicklungsmuster wider, abhängig davon, ob diese funktionalen Grenzen festgelegt werden, um räumliche Muster von Beschäftigung und Pendelverkehr zu einem gegebenen Zeitpunkt zu erfassen oder ob sie den aktuellen Strukturen angepasst werden. Aus nachvollziehbaren Gründen bewirkt dies einen viel grösseren Unterschied in den Resultaten zwischen Städten. Die Anpassung der funktionalen Grenzen Londons zum Beispiel zeigt einen viel grösseren Unterschied zu dessen messbarer Grösse als dies in Paris der Fall ist. London und Londons Bevölkerung hatten traditionsgemäss einen grösseren Pendlereinzugsbereich und Segregationsgrad als Städte auf dem europäischen Kontinent, besonders Paris. Diese haben sich erneut verstärkt durch die Landnutzungsplanung, welche eine starke Kraft für das Wachstum Londons auslöst, das sich bis in den Südosten Englands erstreckt und SatellitenStädte hervorbringt. Trotz der Probleme der statistischen Erfassung gibt es Anhaltspunkte dafür, dass sich in London im Vergleich zu anderen grösseren Städten der EU eine massive Trendwende abgezeichnet hat und zwar absolut und relativ. In jüngster Zeit zeichnen sich Bevölkerungswachstum, Reurbanisierung und eine verbesserte Leistungsstärke der Wirtschaft $a b$.

\section{Résumé: Des définitions urbaines utiles relatives à Londres: Etude comparée de concepts alternatifs de Londres}

Le modèle de développement de Londres illustre l'importance de la définition urbaine et des problèmes 
posés par elle. Le modèle observé est fondamentalement différent selon que Londres est étudié à partir de données reposant sur des définitions administratives ou selon que cette étude est basée sur des limites fonctionnelles. Même la réponse à une question apparemment simple, à savoir si Londres s'accroît ou se réduit, est tributaire de la définition de Londres; c'est le cas aussi dès que l'on analyse l'ambiguïté de Londres: la ville est-elle en voie de décentralisation, en voie de recentralisation ou devient-elle plus petite. Même des définitions fonctionnelles de Londres et de villes de l'Union européenne reflètent des images différentes sur le développement urbain relatif, selon qu'elles s'appuient sur des limites fonctionnelles pour appréhender des modèles d'emplois et de migrations en un moment donné ou selon qu'elles sont adaptées aux structures actuelles. Les résultats des études menées révèlent des différences prononcées entre les villes. L'adaption des limites fonctionnelles de Londres fait p.ex. ressortir un plus grand écart par rapport à la grandeur mesurable de cette ville qu'en ce qui concerne Paris. Londres et sa population disposaient traditionnellement d'un espace migratoire plus ample et étaient marquées par un degré de ségrégation plus important que des villes du continent, Paris en particulier. Ces caractéristiques se sont renforcées à nouveau par la planification en matière d'occupation du sol, qui suscite une forte croissance en faveur de Londres, une croissance qui s'étend jusque dans le sud-est de l'Angleterre et provoque l'apparition de villes-satellites. En dépit des problèmes posés par l'appréhension statistique, des indices font apparaître que Londres a fait l'objet d'un imposant tournant, en chiffres absolus et relatifs, par comparaison avec d'autres villes de l'Union européenne. Tout récemment se sont précisés des phénomènes de croissance démographique, de réurbanisation, ainsi qu'une plus grande efficacité économique.

Prof. Dr. Paul Cheshire, Dr. Galina Gornostaeva, London School of Economics, Department of Geography \& Environment, Houghton Street, GB-London WC2A $2 \mathrm{AE}$.

e-mail:

p.cheshire@lse.ac.uk

g.gornostaeva@lse.ac.uk

Manuskripteingang/received/rentrée du manuscrit: 31.7.2001

Annahme zum Druck/accepted for publication/accepté pour l'impression: 31.10 .2001 